\title{
IMPACTS OF BIOTURBATION FROM TUBIFICIDAE ON THE ELECTROCHEMICAL PERFORMANCE AND MICROBIAL COMMUNITY OF SEDIMENT MICROBIAL FUEL CELLS
}

\author{
XU, P. ${ }^{1}-$ WANG, H. P. ${ }^{1}-$ WANG, X. $.^{1 *}-$ YANG, W. L. ${ }^{2}-$ YU, E. H. ${ }^{3}-$ YAN, X. J. ${ }^{1}$ \\ ${ }^{I}$ School of Resource and Environmental Sciences, Hubei International Scientific and \\ Technological Cooperation Base of Sustainable Resource and Energy, Wuhan University, \\ Wuhan 430079, China \\ ${ }^{2}$ Department of Civil and Environmental Engineering, The Pennsylvania State University, \\ University Park, PA 16802, USA \\ ${ }^{3}$ School of Engineering, Newcastle University, Newcastle upon Tyne, NE1 7RU, UK \\ *Corresponding author \\ e-mail:xu.wang@whu.edu.cn; phone: +86-27-6877-5637 \\ (Received $3^{\text {rd }}$ Apr 2019; accepted $17^{\text {th }}$ May 2019)
}

\begin{abstract}
Sediment microbial fuel cells (SMFCs) have been examined extensively for bioremediation, but the impact of organisms that live in the sediment has not been previously investigated. In this study, the impacts from the bioturbation of Tubificidae on the electrochemical performance and microbial community of SMFCs were investigated using lake water and sediment. It was observed that Tubificidae were burrowing in the sediment and eventually dwelled on the anode of SMFCs. Although the voltage output of the SMFC in the presence of Tubificidae experienced a dramatic decline at the beginning of operation, it outperformed that of the SMFC in the absence of Tubificidae after operating for 30 days. The polarization curves of the SMFC anode and Shannon diversity index suggested that the anodic biofilm was devoured by Tubificidae. However, the cathode performance was improved due to more chemical oxygen demand $(\mathrm{COD})$ and ammonia-nitrogen $\left(\mathrm{NH}_{3}-\mathrm{N}\right)$ released from the sediment. After 90 days of operation, a high loss on ignition (LOI) removal efficiency of $24.5 \pm 3 \%$ was achieved by combining the anodic oxidation of SMFC and the ingestion of Tubificidae. This study shows that SMFCs can alleviate the impact of Tubificidae on pollutants transfer to overlying water and still remove organic matters from the sediment effectively.
\end{abstract}

Keywords: bioturbation, ingestion, organic matters removal, sediment microbial fuel cells, Tubificidae

\section{Introduction}

Freshwater bodies (e.g., lakes, rivers and reservoirs) are crucial resources for drinking water supply, agricultural irrigation and industrial activities. However, water contamination has posed a severe challenge to the sustainability of freshwater resources and is arousing worldwide concerns ( $\mathrm{Li}$ and $\mathrm{Yu}, 2015$ ). Sediment is the natural sink of pollutants in the aquatic environment (Peng et al., 2009; Kanzari et al., 2014; Payne et al., 2013). Previous studies have revealed that various pollutants released from the sediment can lead to water contamination when the external input of pollutants (e.g., agricultural runoffs, effluents from wastewater treatment plants and factories, etc.) is low (Qin, 2002). Therefore, it is of great importance to take measures to alleviate pollutant transfer from the sediment to the aquatic environment.

Sediment microbial fuel cells (SMFCs) have attracted increasing attention for their environmental remediation of freshwater bodies (Wang et al., 2016; Chen et al., 2012; Franco et al., 2018; Yan et al., 2012; Xia et al., 2015; Zhao et al., 2016; Shiriny and 
Bayareh, 2018; Sajana et al., 2014). In most SMFCs, anodes are buried beneath the anaerobic sediment and cathodes are placed in the aerobic overlying water. Exoelectrogenic microorganisms on the anode degrade organic matter and release electrons to the anode and then through the external circuit to the cathode. Finally, dissolved oxygen (DO) and protons in water combine with electrons to produce water and electricity ( $\mathrm{Li}$ and $\mathrm{Yu}, 2015)$. Compared to other techniques, such as dredging, ozonation and intruding bio-agents, SMFCs using bacteria from environment therefore has least impact on natural environment, and also it is self-sustained by generating electricity (Aloisio et al., 2018; Franco et al., 2018; Li and Yu, 2015; Li et al., 2017; Payne et al., 2013; Sherafatmand and Ng, 2015; Xia et al., 2015). For example, SMFC can increase the redox potential of sediment by oxidizing the organic matters and thus the methane (greenhouse gas) production can be inhibited (Hong et al., 2008b). Polycyclic aromatic hydrocarbons (PAHs) is a class of contaminations from the incomplete combustion of fossil fuels. These compounds are of major public concern due to their toxicity to organisms in carcinogenic and mutagenic potential. SMFCs were used for the removal of PAHs under anaerobic or aerobic conditions (Sherafatmand and $\mathrm{Ng}, 2015)$, and with good removal rates of naphthalene (76.9\%), acenaphthene and phenanthrene under anaerobic conditions, while producing a power density of $3.63 \pm 0.37 \mathrm{~mW} \cdot \mathrm{m}^{-2}$. Beside PAHs, cyanobaterial bloom biomass and total petroleum hydrocarbon (TPH) can be effectively degraded by microorganisms on the bioanode of SMFCs (Morris and Jin, 2012; Zhou et al., 2015). The biocathode of SMFCs can be used for in-situ denitrification (Wang et al., 2016; Zhang and Angelidaki, 2012). The results suggested that the SMFC with a small external resistance was more effective for the in-situ denitrification. In addition, the acclimated SMFC biocathode contained mixed microbial communities which could facilitate denitrification, oxygen reduction and ammonia oxidation reactions (Wang et al., 2016). Recently, an SMFC with a novel tubular air cathode was proposed for facilitating air transfer to the cathode (Yuan et al., 2010), which greatly improved biodegradation efficiencies. Additionally, phosphorous flux from overlying water to sediment can be enhanced by employing SMFCs which can oxidize $\mathrm{Fe}^{2+}$ to $\mathrm{Fe}^{3+}$ and store phosphorous substances in sediment in stable forms (Yang et al., 2016). There are numerous reports in improving the performance of SMFCs. Abazarian et al. revealed that SMFC voltage increased when cells connected in series (Abazarian et al., 2016). However, voltage reversal occurred in this case which causes the total voltage to be less than the sum of individual cell voltages in the channel (Abazarian et al., 2016). Placing sheet iron out of the circuit can improve the iron reduction microbial activity. Within the circuit, it produces a large number of electrons from the electrochemical corrosion yielding higher power production (Zhang et al., 2015). An algae assisted cathode was also proposed for SMFCs and the performance was 2.4 fold higher than that of the SMFC with bare cathode (Wang et al., 2014).

While significant progress of SMFCs for bioremediation has been made, there are still many unclear effects from real aquatic environment on the electrochemical performance and microbial community structure of SMFCs. Oligochaetes include the tubificids, pot worms and ice worms (Enchytraeidae), blackworms (Lumbriculidae) and several interstitial marine worms. They are bottom invertebrates frequently used for evaluating the quality of freshwater habitats under their trophic conditions (Krodkiewska and Michalik-Kucharz, 2009). They can be widely distributed in natural water bodies, and they are considered as one of the major bioturbation sources (e.g., feeding, burrowing and locomotory activities) in sediments (Fisher et al., 1980). 
Bioturbation can not only cause significant mixing of freshwater bodies with sediment, but it also changes the physical and chemical properties of the sediment. In this work, SMFCs were constructed with carbon felt which is a cheap, stable and biocompatible material (Christwardana et al., 2018; Huong Le et al., 2017). Oligochaetes community was first analyzed, and then they were introduced to SMFCs (1.0 L beakers). During 90 days of operation, bioturbation by Oligochaetes was monitored, and their impacts on the overlying water, electrochemical performance of whole cell and each electrode were investigated. 16S rDNA pyrosequencing was conducted to analyze the anodic microbial communities of the SMFCs.

\section{Materials and methods}

\section{Sampling and analysis}

Surface sediments ( 0 to $\sim 10 \mathrm{~cm}$ ) were collected using a grab sampler $(2.0 \mathrm{~L})$ from Xinghu Lake $\left(114.366037^{\circ} \mathrm{E}, 30.533637^{\circ} \mathrm{N}\right)$ near Wuhan University, China. Sediment samples were sieved through a $1.0 \mathrm{~mm}$ sieve to remove large debris and then mechanically homogenized. The freshwater was collected from the same location and used throughout the experiment without further treatment. All samples were stored in a refrigerator at $4.0^{\circ} \mathrm{C}$. The LOI of sediment samples was determined using the procedure described previously at a temperature of $550^{\circ} \mathrm{C}$ for $2 \mathrm{~h}$ (Hong et al., 2008a). Chemical oxygen demand (COD) and $\mathrm{NH}_{3}-\mathrm{N}$ of the freshwater were analyzed according to APHA Standard Methods. $\mathrm{pH}$ and conductivity of the overlying water were measured by an electrode probe (Shanghai INESA Scientific Instrument Co., Ltd., China). The DO in the overlying water was monitored everyday using a portable multimeter (HQ30D, Hach, USA) and the DO in the sediment was measured five times to avoid severe oxygen penetration to SMFC anodes. All measurements were taken at least 3 times.

Oligochaetes were provided by the Institute of Hydrobiology, Chinese Academy of Sciences. They were examined under an Olympus BX60 microscope equipped with a DP12 digital camera and AnaliSIS 3.2 (Soft Imaging System) software. Limnodrilus (with smaller sizes) have no caudal gills and can be further divided into Limnodrilus hoffmeisteri and Limnodrilus claparedeianus according to their mature sexual organs; Branchiura (which are mainly Branchiura sowerbyi) are bigger than Limnodrilu and have conspicuous gills in their tails. The tails of Branchiura often cross the sediment and swing in water to breathe oxygen. Overall, Tubificidae was identified as the predominant species (Fig. 1).

\section{SMFC construction and operation}

Graphite felt $5.0 \mathrm{~mm}$ in thickness (Zhongxin Co. Ltd., China) was washed thoroughly with ethanol and DI water before use. Then, it was cut into circular wafers $7.5 \mathrm{~cm}$ in diameter $\left(\sim 44.2 \mathrm{~cm}^{2}\right)$ for use as the SMFC electrodes. The distance between the anode and the cathode was fixed at $7.0 \mathrm{~cm}$. The SMFC was placed into a $1.0 \mathrm{~L}$ beaker and the anode was buried $3.0 \mathrm{~cm}$ below the sediment-water interface. Afterwards, the beaker was transferred to a larger container $(10 \mathrm{~L})$ which contained 3.0 L of freshwater, and a flow rate of $1.0 \mathrm{~L} \cdot \mathrm{h}^{-1}$ was maintained in the SMFC reactor using a peristaltic pump (Fig. 2). The purpose of this reactor design was to constrain Oligochaetes in a small area and also maintain the DO in the reactor at a relatively high level (due to the larger area) for inoculating the biocathode of the SMFC. An external 
resistance of $500 \Omega$ was used to connect the electrodes using titanium wires. After startup for approximately 35 days, the SMFC was transferred to a beaker with fresh sediment. Then, Oligochaetes (with a density of about 2000 ind. $0.1 \mathrm{~m}^{-2}$ ) were added into a beaker (denoted as TUB-1). For comparison, the reactors only containing sediment, only containing Tubificidae and only containing SMFC were assembled (denoted as Control-S, Control-T and TUB-0). All reactors were kept in incubators at $25^{\circ} \mathrm{C}$ for 90 days. The reactors were routinely replenished with DI water to maintain a constant water level.

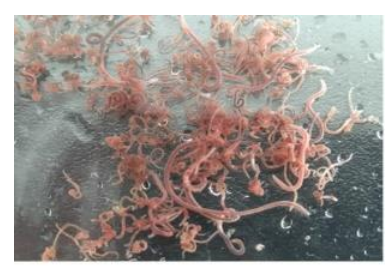

(a)

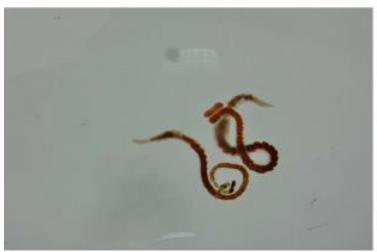

(c)

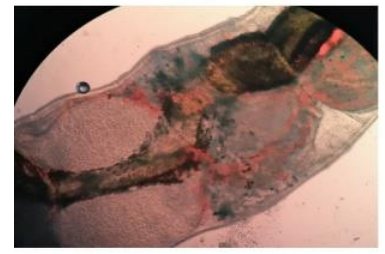

(e)

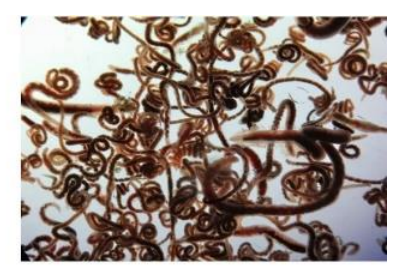

(b)

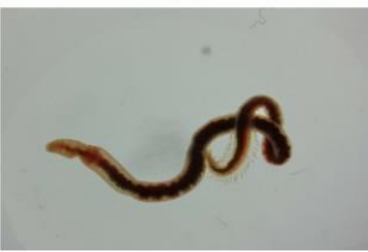

(d)

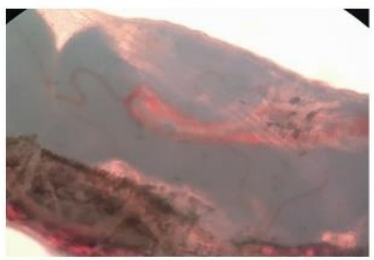

(f)

Figure 1. Optical images of sub-species: $\boldsymbol{a}$ and $\boldsymbol{b}$ Tubificidae under microscope; $\boldsymbol{c}$ Limnodrilus; $\boldsymbol{d}$ Branchiura Sowerbyi; $\boldsymbol{e}$ The penis sheath of Limnodrilus Hoffmeisteri; $\boldsymbol{f}$ The penis sheath of Limnodrilus Claparedeianus

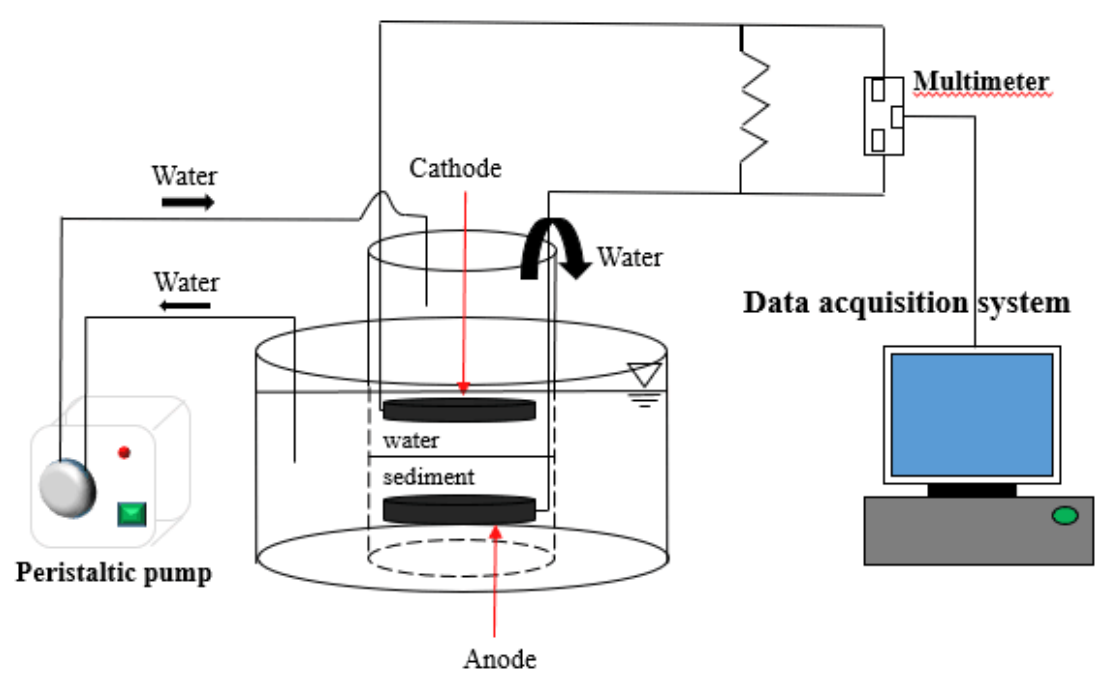

Figure 2. Schematic diagram of experimental setup 


\section{Electrochemical characterization}

The voltage of external resistance was recorded at $10 \mathrm{~min}$ intervals using a data acquisition system (Model 2700, Keithley Instrument, USA). Polarization curves were obtained at a scan rate of $0.1 \mathrm{mV} \cdot \mathrm{s}^{-1}$ using a potentiostat (CHI 604E, Chenhua instrument Co., Ltd., China). Electrode potential were recorded and reported versus $\mathrm{Ag} / \mathrm{AgCl}(3.0 \mathrm{M} \mathrm{KCl}$, saturated $\mathrm{AgCl})$. The power density can be calculated by the obtained voltage using Equation 1:

$$
\mathrm{P}=\mathrm{I} \times \mathrm{U}
$$

where $\mathrm{P}$ is the power density $\left(\mathrm{mW} \cdot \mathrm{m}^{-2}\right), \mathrm{I}$ is the current density $\left(\mathrm{mA} \cdot \mathrm{m}^{-2}\right)$ and $\mathrm{U}$ is the voltage output $(\mathrm{V})$.

\section{Microbial community analysis}

For high-throughput MiSeq Illumina sequencing of the 16S rDNA, biofilms on the anode of SMFC were sampled after 90 days by repeatedly scraping the cross-section of the graphite felt electrode using a sterile blade. The DNA extraction kit (MOBIO Laboratories, CA, USA) was used for extracting $250 \mathrm{mg}$ DNA from the sample. The purity and concentration of DNA were checked through running samples on $1.0 \%$ agarose gels. DNA was amplified following the protocol described previously (Wang et al., 2016). PCR amplifications were conducted in triplicate with the primer set 515F (5'GTGCCAGCMGCCGCGGTAA-3') and 926R (5'-CCGTCAATTCMTTTGAGTTT$\left.3^{\prime}\right)$ that amplifies the V4-V5 region of the 16S rDNA.

Sequencing was determined on an Illumina MiSeq platform. The 16S rDNA gene sequences generated were analyzed using the bioinformatic software package Mothur using the MiSeq SOP Pipeline to analyze a multiplexed set of samples on a single run. The paired reads were assembled using make.contigs that extract the sequences and quality score data from the fastq files, which creates the reverse complement of the reverse read. Then, the paired end reads were assembled into a contig. Screen.seqs which was used to remove low quality reads by the following filtering parameters, maxambig $=0$, minlength $=200$ and maxlength $=580$, maxhomop=8. The remained sequences were simplified using the unique.seqs command to generate a unique set of sequences, and they were aligned with the SILVA databases (version 119). The filter.seqs was used to remove empty columns from our alignment, which provided short length of filtered alignment. Further de-noise sequences were pre-clustered using the pre.cluster command (http://www.mothur.org/wiki/Pre.cluster) for up to 4 differences between sequences. All reads were checked for chimeras using UCHIME algorithm and the chimeric sequences were removed by the chimera.uchime command with default parameters. Silva 119 reference sequence files were used to classify (classify.seqs) our sequences, then the Wang method was used with a confidence threshold of $80 \%$. No-bacteria sequences were deleted. The distance matrix between the aligned sequences was generated by the dist.seqs command. At last, these sequences were clustered to OTUs (operational taxonomic units) at $97 \%$ sequence identity (furthest neighbor method). A majority consensus taxonomy for each OTU was obtained by the classify.otu command with default parameters. 


\section{Results and discussion}

\section{Impacts of Tubificidae on the water quality and loss on ignition (LOI) in the sediment with and without SMFC}

The bioturbation of Tubificidae and SMFC both have profound impact on the sediment and overlying water. $\mathrm{COD}, \mathrm{NH}_{3}-\mathrm{N}$ and organic matter are important indicators of contaminations in natural water bodies and they are also the food for bacteria on SMFCs.

The chemical oxygen demand (COD) and $\mathrm{NH}_{3}-\mathrm{N}$ concentrations in all reactors except Control-T declined rapidly during the initial 25 days, their degradation rates were sluggish after 25 days (Fig. $3 a$ and $b$ ). The removal rate of $\mathrm{NH}_{3}-\mathrm{N}$ was accelerated after 15 days because high COD concentration inhibits ammonia oxidation (Fig. 3b) (Hanaki et al., 1990). For Control-T, the final COD and $\mathrm{NH}_{3}-\mathrm{N}$ were highest $(20.0 \pm 0.15 \mathrm{mg} \bullet \mathrm{L}-1$ and $0.98 \pm 0.04 \mathrm{mg} \bullet \mathrm{L}-1)$, which suggested the bioturbation from Tubificidae can accelerates the release rate of pollutants from the lake sediment (Fisher et al., 1980). The final COD $(9.8 \pm 0.5 \mathrm{mg} \bullet \mathrm{L}-1)$ and $\mathrm{NH}_{3}-\mathrm{N}(0.56 \pm 0.02 \mathrm{mg} \cdot \mathrm{L}-1)$ were much lower in TUB-1. Previous reports revealed that the biocathode of SMFCs can digest COD as carbon/food sources for bacterial metabolism (Sajana et al., 2014). It is worth of noting that the $\mathrm{NH}_{3}-\mathrm{N}$ was significantly removed in Control-S, which is similar to that in TUB-0. However, the final CODs in TUB-0 $(8.5 \pm 0.13 \mathrm{mg} \cdot \mathrm{L}-1)$ was around $6 \mathrm{mg} \cdot \mathrm{L}^{-1}$ lower than that in Control-S. It is well-known in wastewater treatment that COD is much easier to be oxidized than $\mathrm{NH}_{3}-\mathrm{N}$ (Hanaki et al., 1990). All parameters can also be found in Table 1 .

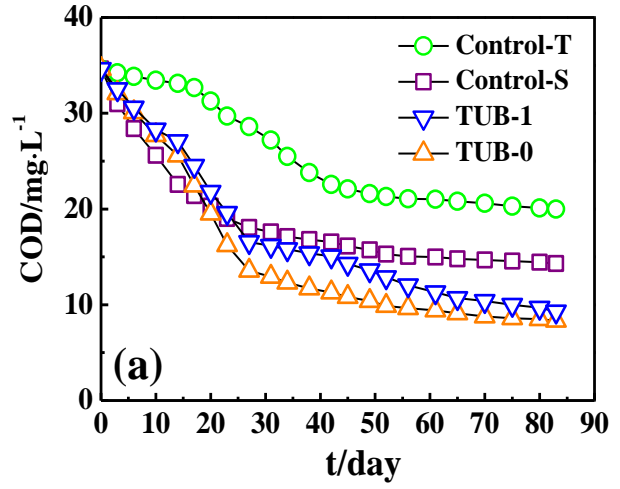

(a) COD

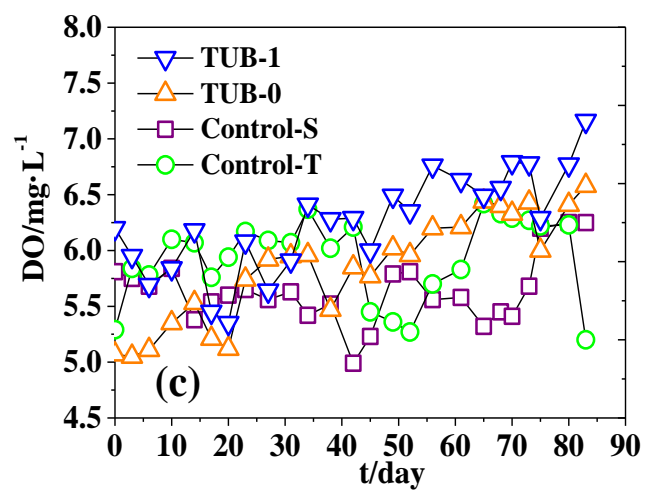

(c) DO

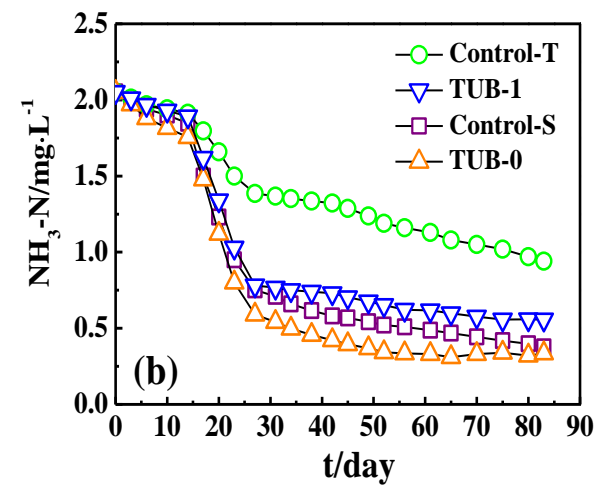

(b) $\mathrm{NH}_{3}-\mathrm{N}$

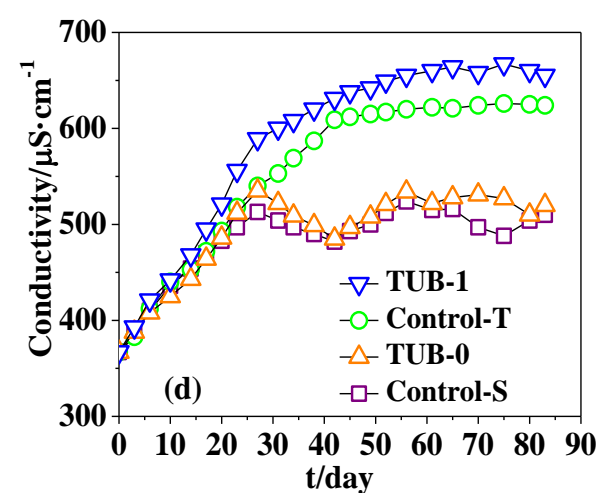

(d) Conductivity

Figure 3. Water quality of the overlying water in different reactors 
The DO in the overlying water in different reactors ranged from 5.0 to $7.0 \mathrm{mg} \cdot \mathrm{L}^{-1}$ (Fig. 3c). The conductivity of the overlying water in all reactors started increase, then it reached a plateau after around 25 days of operation. The conductivities in TUB-1 $\left(660 \pm 5.0 \mu \mathrm{S} \bullet \mathrm{cm}^{-1}\right)$ and Control-T $\left(624 \pm 2.0 \mu \mathrm{S} \bullet \mathrm{cm}^{-1}\right)$ after 25 days of operation were higher than that in TUB-0 $\left(519 \pm 8.0 \mu \mathrm{S} \bullet \mathrm{cm}^{-1}\right)$ and Control-S $\left(500 \pm 11.0 \mu \mathrm{S} \bullet \mathrm{cm}^{-1}\right)$ (Fig. 3d). During these measurements, it was observed that Tubificidae was burrowing in the sediment and formed tunnels that can increase the releasing rate of soluble chemical compounds (e.g. soluble $\mathrm{COD}, \mathrm{NH}_{4}{ }^{+}$and sulfates) (Fig. 4) (Mccaffrey et al., 1980; Florian and Lemoine, 2010). SMFCs enhanced the degradation of COD and $\mathrm{NH}_{3-}$ $\mathrm{N}$ in the overlying water using bio-cathodes, which is consistent with previous reports (Wang et al., 2016; Li et al., 2017). In addition, the DO inside the sediment of ControlT and TUB-1 was also measured and the results were low in two reactors even when the sediment became more porous (Table 1). This is due to the strong respiration effect from Tubificidae and they consumes the most of DO in the sediment (Lou et al., 2013).
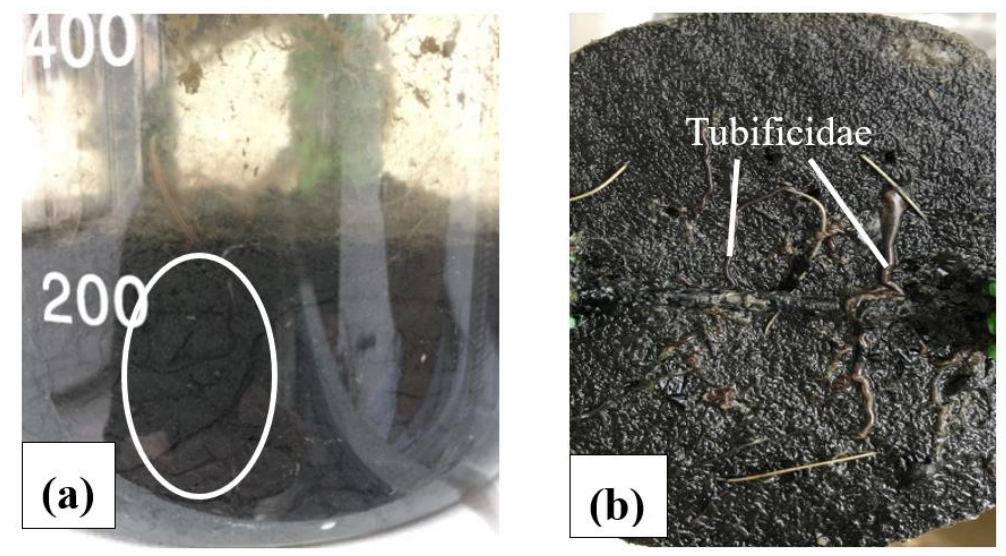

Figure 4. Optical image of a tunnels from Tubificidae burrowing and $\boldsymbol{b}$ the SMFC anode in TUB-1

Table 1. $p H$ and pollutant concentration in the overlying water and DO in the sediment

\begin{tabular}{c|c|c|c|c}
\hline Samples & Control-S & Control-T & TUB-0 & TUB-1 \\
\hline $\mathrm{pH}$ & $8.10 \pm 0.16$ & $7.98 \pm 0.12$ & $7.96 \pm 0.17$ & $8.12 \pm 0.12$ \\
$\mathrm{DO}(\mathrm{mg} / \mathrm{L})$ & $0.48 \pm 0.06$ & $0.21 \pm 0.01$ & $0.17 \pm 0.03$ & $0.14 \pm 0.04$ \\
Initial COD concentration(mg/L) & $34.6 \pm 0.01$ & $34.6 \pm 0.01$ & $34.6 \pm 0.01$ & $34.6 \pm 0.01$ \\
Final COD concentration (mg/L) & $14.5 \pm 0.16$ & $20.0 \pm 0.15$ & $8.5 \pm 0.13$ & $9.8 \pm 0.5$ \\
$\mathrm{COD}$ removal efficiency & $58.1 \%$ & $42.2 \%$ & $76.0 \%$ & $71.7 \%$ \\
Initial $\mathrm{NH}_{3}-\mathrm{N}$ concentration (mg/L) & $2.05 \pm 0.01$ & $2.05 \pm 0.01$ & $2.05 \pm 0.01$ & $2.05 \pm 0.01$ \\
Final $\mathrm{NH}_{3}-\mathrm{N}$ concentration $(\mathrm{mg} / \mathrm{L})$ & $0.38 \pm 0.01$ & $0.98 \pm 0.04$ & $0.33 \pm 0.01$ & $0.56 \pm 0.02$ \\
$\mathrm{NH}_{3}-\mathrm{N}$ removal efficiency & $81.6 \%$ & $54.2 \%$ & $83.6 \%$ & $72.8 \%$ \\
\hline
\end{tabular}

The largest decrease $(24.5 \pm 3 \%)$ of LOI in the sediment was obtained using the SMFC in TUB-1 (Fig. 5). Numerous investigations reported that Tubificidae ingest organic matters effectively and thus be used for sludge minimization (Lou et al., 2013; Wei et al., 2003). The SMFC in TUB-0 exhibited a LOI removal efficiency of $16 \pm 1.5 \%$ which was similar to that in Control-T $(16.3 \pm 1.5 \%)$ while it was only 
$2.2 \pm 1 \%$ in Control-S. A LOI removal efficiency of $\sim 22 \%$ after 6 months of operation was reported in the field test using the SMFC under a closed-circuit condition (Hong et al., 2008a, b). The higher electrochemical performance of SMFCs and the bioturbation of Tubificidae were attributed to the high LOI removal efficiency $(24.5 \pm 3 \%)$ in this work.

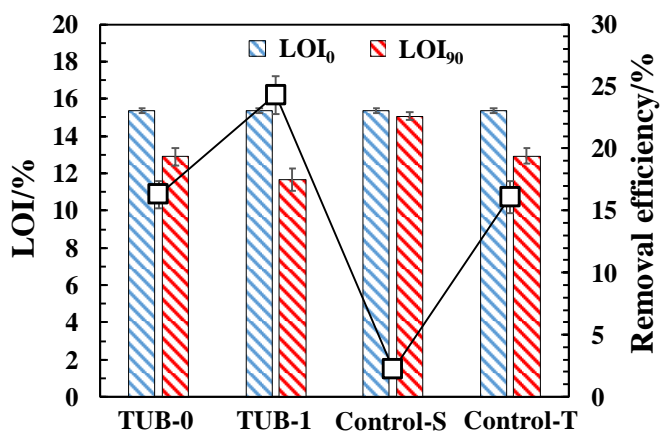

Figure 5. LOI changes in the sediment. LOIO and LOI9O represent the initial and final values of LOI in the sediment. Error bars indicate range of duplicate results

\section{Electrochemical performance of SMFCs in the presence and absence of Tubificidae}

Tubificidae does not just redistributed the pollutants, they also inter-reacted with the electrodes of SMFCs. After 9 days of Tubificidae addition, the voltage output of SMFC started to decline steeply from around $300 \mathrm{mV}$ to $130 \mathrm{mV}$ (Fig. 6). Meanwhile, there was no visual on Tubificidae burrowing in the sediment after 10 days since the SMFC was transferred to the container of TUB-1. At the end of 90 day's operation, electrodes were removed from containers and it was found that Tubificidae dwelled in the porous graphite felt electrodes (Fig. 4). Previous studies revealed that Oligochaetes spent their life in the root zone of aquatic plants and other organic matter enriched areas (e.g. plant debris, bacteria) for food (Rota and De Jong, 2015; Vanamala Naidu et al., 1981). They can assimilate organic detritus and bacteria (Kemp, 1987). In this study, the SMFC anode acted as the root zone of aquatic plants and the biofilm on the electrode could be ingested by bioturbators, which caused the loss of the electrochemical performance.

However, it was found that the cell voltage in TUB-1 increased and it exceeded the initial value and the voltage of the SMFC in TUB-0 at day 30. To further examine the potential changes of electrodes, linear sweep voltammetry (LSV) was conducted in a three-electrode system (Fig. 7a). Before Tubificidae addition, the reaction rate on the cathode (upper figure) was slow and it was the limiting step of whole cell reaction compared to the anode. Once the SMFC was transferred to the Tubificidae containing sediment, the anode performance decreased in terms of open circuit potential (OCP) and limiting current. After $\sim 30$ days of operation, the anode performance partially recovered except for OCP. It was reported that the low concentration of DO significantly reduced the respiration rate of Tubificidae (Van Hoven, 1975), hence the anodic biofilm of the SMFC in TUB-1 could be recovered to some extent. On the other hand, the electrochemical performance of whole cell SMFCs (data not shown) and electrodes in the absence of Tubificidae decreased slightly after 50 days (Fig. 8). Although the increase of DO in the sediment was claimed by previous reports to be responsible for the performance drop due to the bacteria on SMFC anode are anaerobic, DO results in the sediment were not monitored or reported (Zhao et al., 2016). In this study, DO 
beneath the sediment remains low during operation in TUB-0 and TUB- 1 . Thus, the performance loss of the SMFC anode in TUB-1 was attributed by the ingestion of worms rather than the increase of DO in the sediment. The cathode performance of the SMFC in TUB-1 was improved significantly after Tubificidae addition for about 30 days. This is because of more $\mathrm{COD}$ and $\mathrm{NH}_{3}-\mathrm{N}$ released from the sediment to the overlying water (Fig. $3 a$ and b). More COD in the overlying water provided more food for the biofilm growth on the cathode. Overall, the SMFC performance in TUB-1 was improved from $70 \mathrm{~mW} \cdot \mathrm{m}^{-2}$ to $93 \mathrm{~mW} \cdot \mathrm{m}^{-2}$ (Fig. $\left.7 b\right)$.

\section{Microbial community analysis}

The microbial community of the pristine sediment, overlying water, anode biofilms of SMFCs in TUB-0 and TUB-1 were analyzed to reveal the enrichment of genera with potential exoelectrogenic capability using $16 \mathrm{~S}$ rDNA pyrosequencing. The diversity index (5.27) of pristine sediment was highest, which is consistent with previous reports (Zhao et al., 2016; Lu et al., 2014). The diversity index of the anodic biofilm in TUB-0 (4.75) was higher than that of the SMFC in TUB-1 (4.50) (Table 2). The result further confirmed the anodic biofilm was consumed by Tubificidae and led a lower diversity index (Fig. 6).

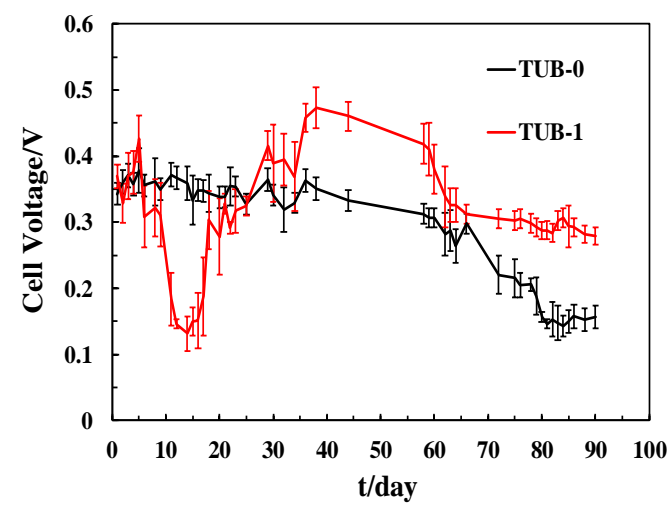

Figure 6. Voltage output of SMFCs with and without Tubificidae. Error bars indicate range of duplicate results
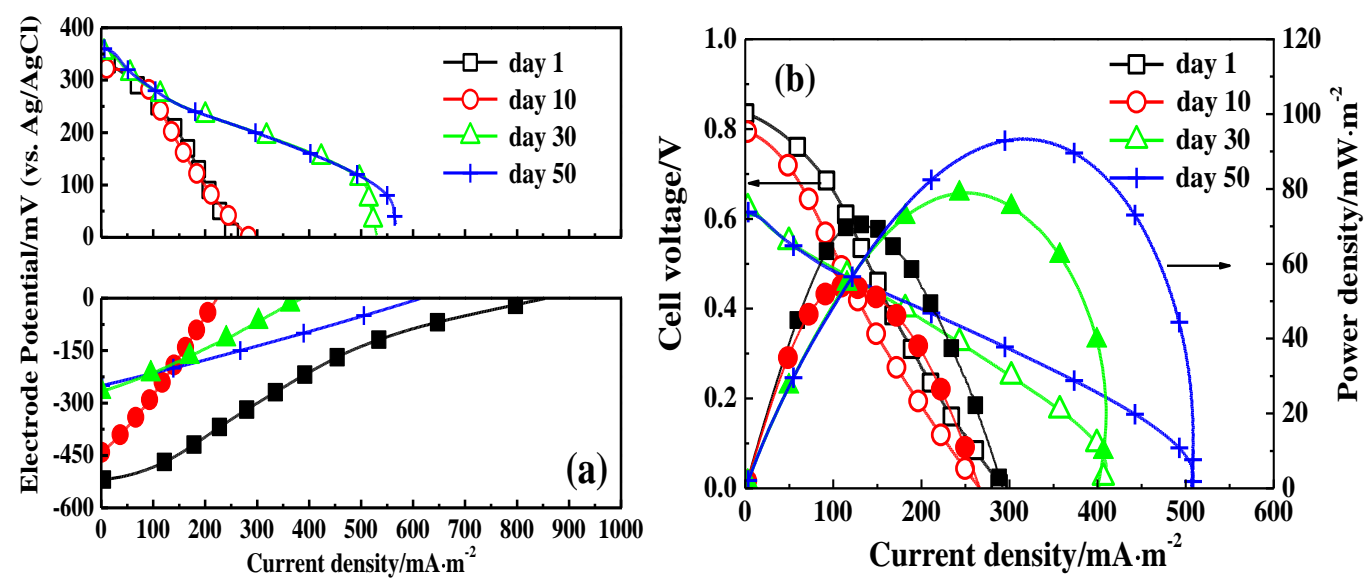

Figure 7. a LSV curves of the SMFC anode and cathode. $\boldsymbol{b}$ Polarization curves of the SMFC in TUB-1 after Tubificidae addition 


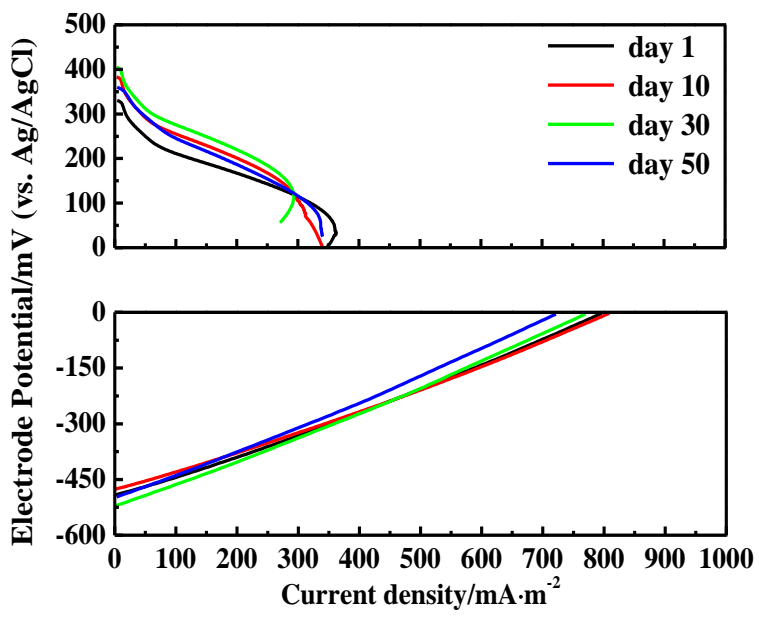

Figure 8. LSV curves of the SMFC anode and cathode in TUB-O

Table 2. Shannon diversity indexes of different samples

\begin{tabular}{c|c}
\hline Samples & Shannon index \\
\hline Pristine sediment & 5.27 \\
Overlying water & 4.0 \\
TUB-0 & 4.75 \\
TUB-1 & 4.51 \\
\hline
\end{tabular}

The taxonomic analysis of bacterial DNA sequences shows that the microbial community of the anodic biofilm of the SMFC with Tubificidae was altered, compared to that of the SMFC without Tubificidae. Specifically, Proteobacteria was the dominant phylum in all samples (Fig. 9) and previous studies reported the same finding (Yan et al., 2015; Logan and Rabaey, 2012).

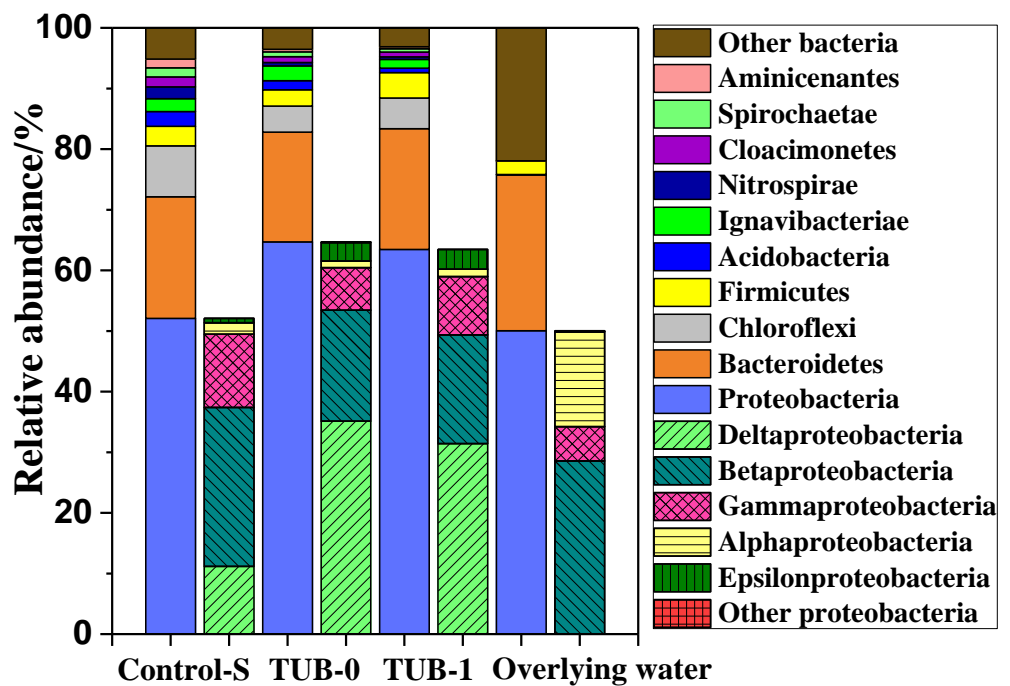

Figure 9. Taxonomic classification of bacterial DNA sequences from the communities of different samples at the phylum level and the most dominant phylum of Proteobacteria at the class level 


$$
-9257 \text { - }
$$

From the class level, Deltaproteobacteria in the anodic biofilm were increased compared to that in the pristine sediment. Desulfobulbus (11.7\%) and Geobacter $(10.3 \%)$ were the dominant genera at genus level in the anodic biofilm of the SMFC in TUB-0 (Fig. 10a and $b$ ).

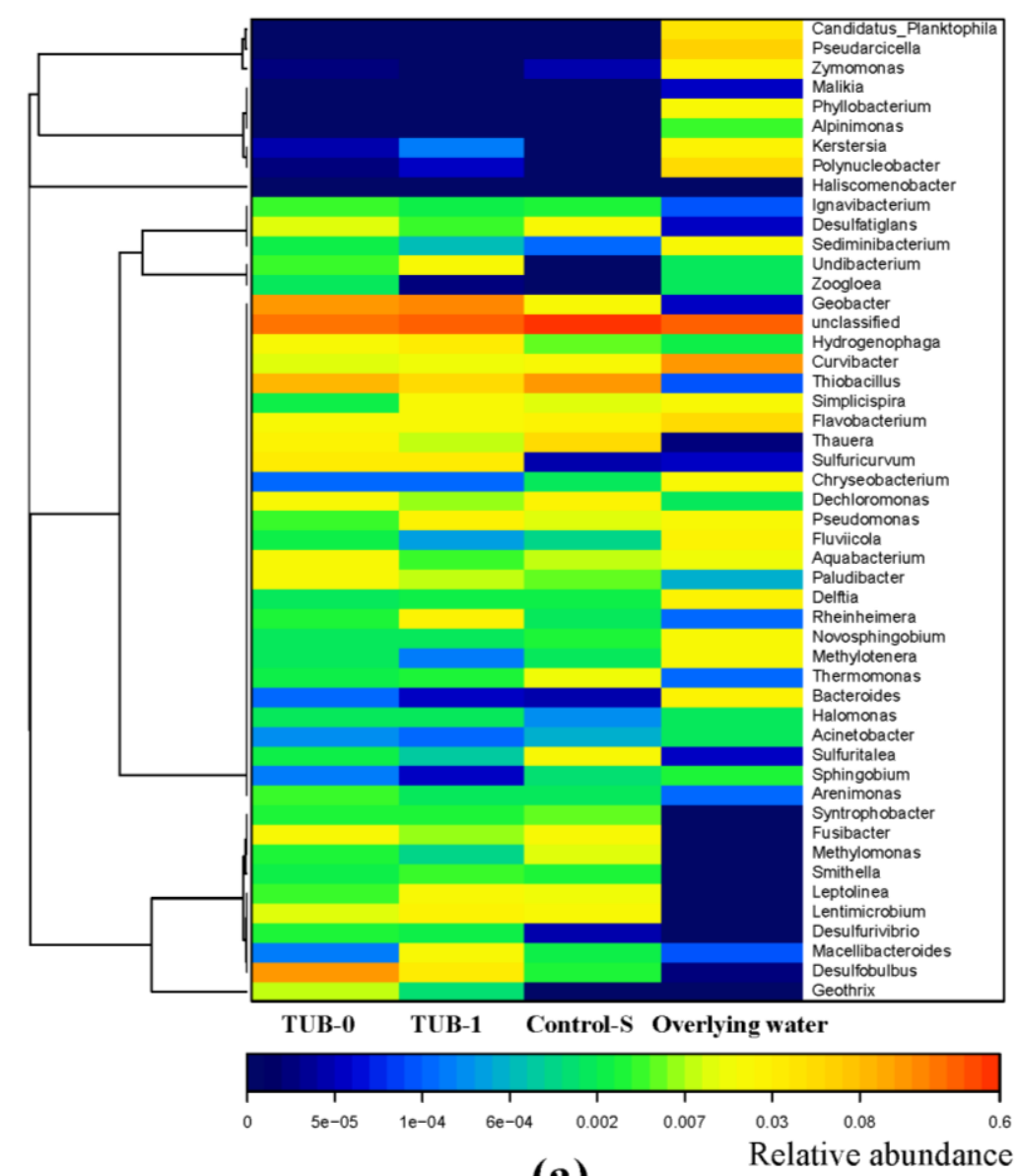

(a)

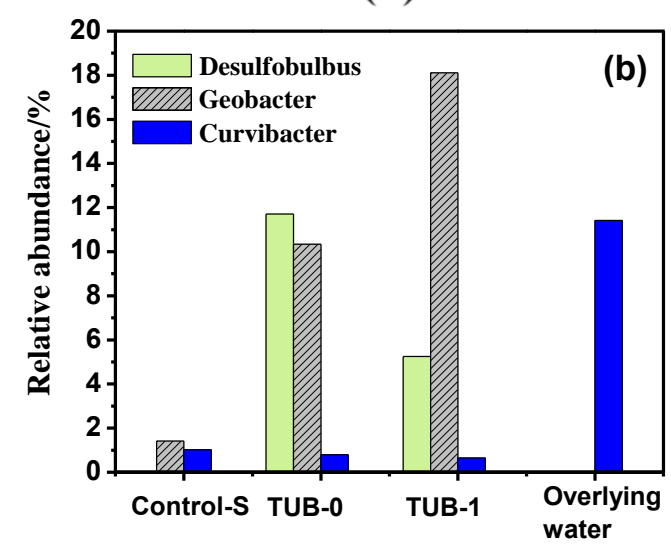

Figure 10. a Heatmap of all samples at the genus level. $\boldsymbol{b}$ The relative abundances of Desulfobulbus, Geobacter and Curvibacter in different samples

Geobacter is well-known bacteria that can directly digest acetic acid or other small organic molecules (e.g. Ethanol) to produce electricity (Logan and Rabaey, 2012). 
Desulfobulbus are also proved to be exoelectrogenic micro-organisms that can oxidize $\mathrm{S}^{0}$ in sediments. Their abundance increased and identified as one of predominant genera in the anodic biofilm of SMFCs as previously reported (Yan et al., 2015; Lu et al., 2015; Ryckelynck et al., 2005). In TUB-1, the predominant genus in the SMFC anode was Geobacter (18.1\%) alone while the relative abundance of Desulfobulbus was only $5.25 \%$. Oligochaetes are the host of several sulfur oxidizing bacteria and these bacteria can compete with Desulfobulbus for the $\mathrm{S}^{0}$ source in the vicinity of bioanodes (Bergin et al., 2018; Blazejak et al., 2005). Hence, the microbial activity of Desulfobulbus was suppressed due to the strong bioturbation of Tubificidae in this study. A similar completion also exists between Geobacter on the anode of SMFC and methanogens on organic matters in sediments for the same substrate. Therefore, the use of SMFC can inhibits methane production from sediment. Thiobacillus, a strain of genera was reported with the ability of using sulfur as energy sources (Boden, 2017), were $9.1 \%$, $7.7 \%$ and $5 \%$ in Control-S, TUB-0 and TUB-1. This result also confirms the competing mechanism described above. Curvibacter was the predominant genus (11.4\%) in the overlying water and it is a well-established aerobic bacterium. The higher abundance of aerobic bacteria (Polynucleobacter, Kerstersi, phyllobacterium, fluviicola) in overlying water was found in most of water bodies (Chen et al., 2017; Halkjær et al., 2009). The low relative abundances of Curvibacter in the sediment of Control-S (1.0\%), the SMFC anode of TUB-0 $(0.8 \%)$ and TUB-1 $(0.64 \%)$ confirmed that the DO beneath the sediment in all reactors remained low during operation.

The protein contents in SMFC electrodes were also examined. However, it was impossible for us to separate worms from the SMFC anode in TUB-1 since they dwelled inside the anode. After 90 days of operation, the protein contents of the SMFC cathode in TUB-1 and TUB-0 were $0.379 \mathrm{~g} \bullet \mathrm{m}^{-2}$ and $0.269 \mathrm{~g} \bullet \mathrm{m}^{-2}$. The higher protein content of the SMFC cathode in TUB-1 suggested that more bacteria enriched on the electrode and resulted in better electrochemical performance (Fig. 7a).

\section{Conclusions}

The present study demonstrated that the organic matter removal and electrochemical performance of SMFCs were enhanced by the bioturbation of Tubificidae. For the first time, it was found that Tubificidae dwelled on the carbon felt anode of SMFCs and devoured the biofilm. After 90 days of operation, a high LOI removal efficiency of $24.5 \pm 3 \%$ was achieved in TUB-1. The SMFC performance in the presence of Tubificidae increased from $70 \mathrm{~mW} \cdot \mathrm{m}^{-2}$ to $93 \mathrm{~mW} \cdot \mathrm{m}^{-2}$. The bioturbation of Tubificidae suppressed the acclimation of Desulfobulbus on the bioanode of SMFCs. The sediment beneath the water-sediment interface remained anaerobic in the presence of Tubificidae.

Acknowledgements. The authors would like to thank Prof. Bruce E. Logan from Penn state University for editing the manuscript and Dr. Yongjing Zhao from the Institute of Hydrobiology, Chinese Academy of Sciences, for providing Oligochaetes samples. This work is financially supported by the national major project of water pollution control and treatment (Grant No. 2017ZX07204004-01), National Natural Science Foundation of China (Grant No.21406171 and No. 51778265) and the Fundamental Research Funds for the Central Universities (Grant No. 2042018kf0244). 


\section{REFERENCES}

[1] Abazarian, E., Gheshlaghi, R., Mahdavi, M. A. (2016): The effect of number and configuration of sediment microbial fuel cells on their performance in an open channel architecture. - Journal of Power Sources 325: 739-744.

[2] Aloisio, D., Ferraro, M., Brunaccini, G., Sergi, F., Randazzo, N., Dispenza, G., Antonucci, V. (2018): Modeling, realization and test on field of a fuel cell-Na/ $\mathrm{NiCl} 2$ battery hybrid system as a base transceiver station power supply. - Instrumentation Mesure Métrologie 17(3): 423-442.

[3] Bergin, C., Wentrup, C., Brewig, N., Blazejak, A., Erséus, C., Giere, O., Schmid, M., De Wit, P., Dubilier, N. (2018): Acquisition of a novel sulfur oxidizing symbiont in the gutless marine worm Inanidrilus exumae. - Applied and Environmental Microbiology 84(7): e02267-17.

[4] Blazejak, A., Erséus, C., Amann, R., Dubilier, N. (2005): Coexistence of bacterial sulfide oxidizers, sulfate reducers, and spirochetes in a gutless worm (Oligochaeta) from the Peru Margin. - Applied and Environmental Microbiology 71(3): 1553-1561.

[5] Boden, R. (2017): Editorial: 115 years of sulfur microbiology. - FEMS Microbiology Letters 364(6).

[6] Chen, J., Zhang, L., Hu, Y., Huang, W., Niu, Z., Sun, J. (2017): Bacterial community shift and incurred performance in response to in situ microbial self assembly graphene and polarity reversion in microbial fuel cell. - Bioresource Technology 241: 220-227.

[7] Chen, Z., Huang, Y. C., Liang, J. H., Zhao, F., Zhu, Y. G. (2012): A novel sediment microbial fuel cell with a biocathode in the rice rhizosphere. - Bioresource Technology 108: 55-59.

[8] Christwardana, M., Frattini, D., Accardo, G., Yoon, S. P., Kwon, Y. (2018): Early stage performance evaluation of flowing microbial fuel cells using chemically treated carbon felt and yeast biocatalyst. - Applied Energy 222: 369-382.

[9] Fisher, J. B., Lick, W. J., McCall, P. L., Robbins, J. A. (1980): Vertical mixing of lake sediments by tubificid oligochaetes. - Journal of Geophysical Research: Oceans 85(C7): 3997-4006.

[10] Florian, M. B., Lemoine, D. G. (2010): Ecosystem engineering by tubificid worms stimulates macrophyte growth in poorly oxygenated wetland sediments. - Functional Ecology 24(2): 444-453.

[11] Franco, F. D., Burgio, G., Santamaria, M. (2018): Chitosan-Heteropolyacid membranes for direct methanol fuel cells. - Revue des Composites et des Matériaux Avancés 28(2): 141-147.

[12] Halkjær, N. P., Caroline, K., J., S. R., Lund, N. J. (2009): Identity and ecophysiology of filamentous bacteria in activated sludge. - FEMS Microbiology Reviews 33(6): 969-998.

[13] Hanaki, K., Wantawin, C., Ohgaki, S. (1990): Effects of the activity of heterotrophs on nitrification in a suspended growth reactor. - Water Research 24(3): 289-296.

[14] Hong, S. W., Chang, I. S., Choi, Y. S., Kim, B. H., Chung, T. H. (2008a): Responses from freshwater sediment during electricity generation using microbial fuel cells. Bioprocess and Biosystems Engineering 32(3): 389-395.

[15] Hong, S. W., Kim, J., Yong, S. C., Tai, H. C. (2008b): Field experiments on bioelectricity production from lake sediment using microbial fuel cell technology. - Bulletin Korean Chemical Society 29(11): 2189-2194.

[16] Huong Le, T. X., Bechelany, M., Cretin, M. (2017): Carbon felt based electrodes for energy and environmental applications: A review. - Carbon 122: 564-591.

[17] Kanzari, F., Syakti, A. D., Asia, L., Malleret, L., Piram, A., Mille, G., Doumenq, P. (2014): Distributions and sources of persistent organic pollutants (aliphatic hydrocarbons, PAHs, PCBs and pesticides) in surface sediments of an industrialized urban river (Huveaune), France. - Science of the Total Environment 478: 141-151. 
[18] Kemp, P. F. (1987): Potential impact on bacteria of grazing by a macrofaunal deposit feeder, and the fate of bacterial production. - Marine Ecology Progress Series 36(2): 151161.

[19] Krodkiewska, M., Michalik Kucharz, A. (2009): The bottom Oligochaeta communities in sand pits of different trophic status in Upper Silesia (Southern Poland). - Aquatic Ecology 43(2): 437-444.

[20] Li, H., Tian, Y., Qu, Y., Qiu, Y., Liu, J., Feng, Y. (2017): A Pilot scale benthic microbial electrochemical system (BMES) for enhanced organic removal in sediment restoration. Scientific Reports 7: 39802.

[21] Li, W. W., Yu, H. Q. (2015): Stimulating sediment bioremediation with benthic microbial fuel cells. - Biotechnology Advances 33(1): 1-12.

[22] Logan, B. E., Rabaey, K. (2012): Conversion of wastes into bioelectricity and chemicals by using microbial electrochemical technologies. - Science 337(6095): 686-690.

[23] Lou, J., Cao, Y., Sun, P., Zheng, P. (2013): The effects of operational conditions on the respiration rate of tubificidae. - PLoS ONE 8(12): e81219.

[24] Lu, L., Huggins, T., Jin, S., Zuo, Y., Ren, Z. J. (2014): Microbial metabolism and community structure in response to bioelectrochemically enhanced remediation of petroleum hydrocarbon contaminated soil. - Environmental Science \& Technology 48(7): 4021-4029.

[25] Lu, L., Xing, D., Ren, Z. J. (2015): Microbial community structure accompanied with electricity production in a constructed wetland plant microbial fuel cell. - Bioresource Technology 195: 115-121.

[26] Mccaffrey, R. J., Myers, A. C., Davey, E., Morrison, G., Bender, M., Luedtke, N., Cullen, D., Froelich, P., Klinkhammer, G. (1980): The relation between pore water chemistry and benthic fluxes of nutrients and manganese in Narragansett Bay, Rhode Island. Limnology and Oceanography 25(1): 31-44.

[27] Morris, J. M., Jin, S. (2012): Enhanced biodegradation of hydrocarbon contaminated sediments using microbial fuel cells. - Journal of Hazardous Materials 213-214: 474-477.

[28] Payne, R. B., Fagervold, S. K., May, H. D., Sowers, K. R. (2013): Remediation of polychlorinated biphenyl impacted sediment by concurrent bioaugmentation with anaerobic halorespiring and aerobic degrading bacteria. - Environmental Science \& Technology 47(8): 3807-3815.

[29] Peng, J. F., Song, Y. H., Yuan, P., Cui, X. Y., Qiu, G. L. (2009): The remediation of heavy metals contaminated sediment. - Journal of Hazardous Materials 161(2-3): 633640.

[30] Qin, B. (2002): Approaches to mechanisms and control of eutrophication of shallow lakes in the middle and lower reaches of the Yangze River. - Journal of Lake Sciences 14(3): 193-202.

[31] Rota, E., de Jong, Y. (2015): Fauna Europaea: annelida terrestrial oligochaeta (Enchytraeidae and Megadrili), aphanoneura and polychaeta. - Biodiversity Data Journal (3): e5737.

[32] Ryckelynck, N., Stecher, H. A., Reimers, C. E. (2005): Understanding the anodic mechanism of a seafloor fuel cell: interactions between geochemistry and microbial activity. - Biogeochemistry 76(1): 113-139.

[33] Sajana, T. K., Ghangrekar, M. M., Mitra, A. (2014): Effect of operating parameters on the performance of sediment microbial fuel cell treating aquaculture water. - Aquacultural Engineering 61: 17-26.

[34] Sherafatmand, M., Ng, H. Y. (2015): Using sediment microbial fuel cells (SMFCs) for bioremediation of polycyclic aromatic hydrocarbons (PAHs). - Bioresource Technology 195: 122-130.

[35] Shiriny, A., Bayareh, M. (2018): Numerical study of heat transfer and pressure drop in a fuel cell with porous material. - Annales de Chimie - Science des Matériaux 42(3): 323 334. 
[36] Van Hoven, W. (1975): Aspects of the respiratory physiology and oxygen preferences of four aquatic oligochaetes (Annelida). - Zoologica Africana 10(1): 29-44.

[37] Vanamala Naidu, K., Kalpana, K. (1981): Suresh Kumar, K., Aquatic oligochaeta from among the roots of eicHhornia crassipes Solms. - Hydrobiologia 76(1): 103-112.

[38] Wang, D. B., Song, T. S., Guo, T., Zeng, Q., Xie, J. (2014): Electricity generation from sediment microbial fuel cells with algae assisted cathodes. - International Journal of Hydrogen Energy 39(25): 13224-13230.

[39] Wang, Y., Hu, J., Wang, L., Shan, D., Wang, X., Zhang, Y., Mao, X., Xing, L., Wang, D. (2016): Acclimated sediment microbial fuel cells from a eutrophic lake for the in situ denitrification process. - RSC Advances 6(83): 80079-80085.

[40] Wei, Y., Van Houten, R. T., Borger, A. R., Eikelboom, D. H., Fan, Y. (2003): Minimization of excess sludge production for biological wastewater treatment. - Water Research 37(18): 4453-4467.

[41] Xia, C., Xu, M., Liu, J., Guo, J., Yang, Y. (2015): Sediment microbial fuel cell prefers to degrade organic chemicals with higher polarity. - Bioresource Technology 190: 420-423.

[42] Yan, Z., Song, N., Cai, H., Tay, J. H., Jiang, H. (2012): Enhanced degradation of phenanthrene and pyrene in freshwater sediments by combined employment of sediment microbial fuel cell and amorphous ferric hydroxide. - Journal of Hazardous Materials 199-200: 217-225.

[43] Yan, Z., Jiang, H., Cai, H., Zhou, Y., Krumholz, L. R. (2015): Complex interactions between the macrophyte Acorus calamus and microbial fuel cells during pyrene and benzo[a]pyrene degradation in sediments. - Scientific Reports 5: 10709.

[44] Yang, Q., Zhao, H., Zhao, N., Ni, J., Gu, X. (2016): Enhanced phosphorus flux from overlying water to sediment in a bioelectrochemical system. - Bioresource Technology 216: 182-187.

[45] Yuan, Y., Zhou, S., Zhuang, L. (2010): A new approach to in situ sediment remediation based on air cathode microbial fuel cells. - Journal of Soils and Sediments 10(7): 14271433.

[46] Zhang, H., Zhu, D., Song, T. S., Ouyang, P., Xie, J. (2015): Effects of the presence of sheet iron in freshwater sediment on the performance of a sediment microbial fuel cell. International Journal of Hydrogen Energy 40(46): 16566-16571.

[47] Zhang, Y., Angelidaki, I. (2012): Bioelectrode based approach for enhancing nitrate and nitrite removal and electricity generation from eutrophic lakes. - Water Research 46(19): 6445-6453.

[48] Zhao, Q., Li, R., Ji, M., Ren, Z. J. (2016): Organic content influences sediment microbial fuel cell performance and community structure. - Bioresource Technology 220: 549-556.

[49] Zhou, Y. L., Jiang, H. L., Cai, H. Y. (2015): To prevent the occurrence of black water agglomerate through delaying decomposition of cyanobacterial bloom biomass by sediment microbial fuel cell. - Journal of Hazardous Materials 287: 7-15. 